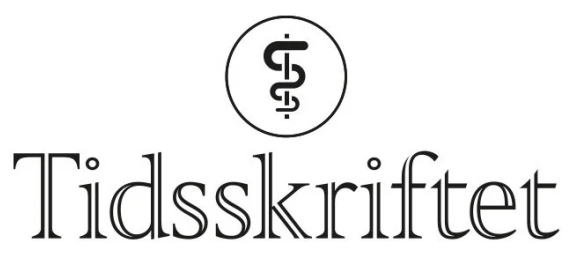

DEN NORSKE LEGEFORENING

\title{
Sprett champagnen
}

\author{
BREV TIL REDAKTØREN
}

\section{OLE PETER NORDBY}

Ole Peter Nordby (f. 1954) er cand.theol., siviløkonom, finansanalytiker CEFA og har studert molekylærbiologi ved Universitetet i Oslo. Han er partner og senior porteføljeforvalter i Sigma Fondsforvaltning.

Oppgitte interessekonflikter: Ole Peter Nordby er ansatt i og medeier i Sigma Fondsforvaltning som har ansvar for og inntekter fra forvaltningen av Sigma Life Sciences. Aksjefondet er investert i Algeta. Sigma Life Sciences 


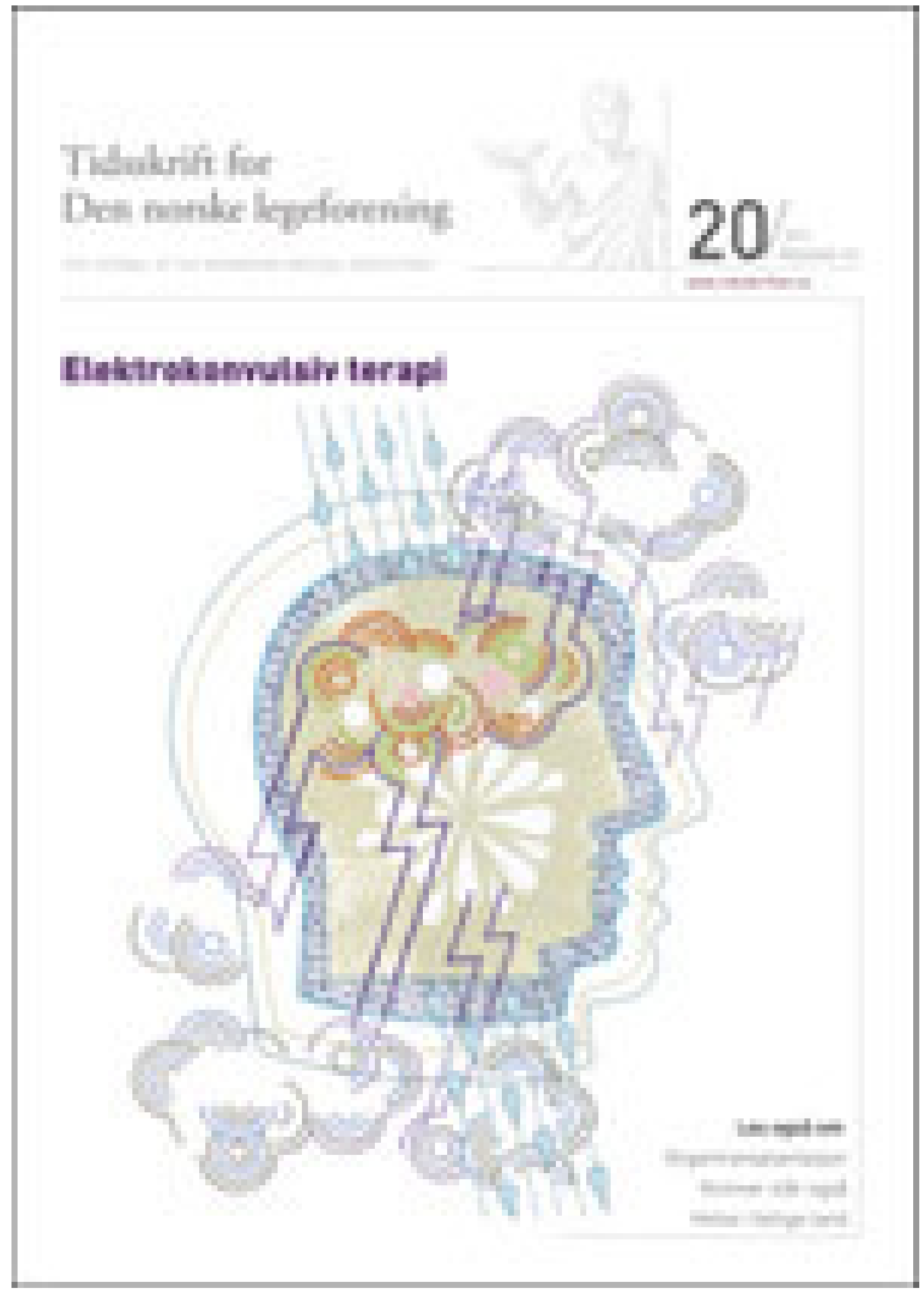

I en leder i Tidsskriftet nr. 20/2011 beskrives helt korrekt det positive hovedresultat som ledet til at Algetas kliniske studie i sommer ble avsluttet før tiden (1). Forfatteren peker også på et problem knyttet til den finansielle vurderingen av forskningsbaserte virksomheter som er børsnotert. Det er imidlertid en noe misvisende konklusjon som trekkes i artikkelen, muligens på basis av en sviktende forståelse av arbeidsdelingen i medisinsk forskning.

De finansielle strukturene rundt akademisk og kommersiell forskning er ulike. Akademiske miljøer får sine midler stort sett fra det offentlige, men det er svært sjelden at det offentlige finansierer pivotale studier som skal legge grunnlag for regulatoriske søknader om godkjennelse av nye legemidler. Akademiske studier vil normalt ikke ha den karakter som den omtalte Algeta-studien hadde. Finansiering av studier i denne prisklassen - som lederartikkelen anfører flere hundre millioner kroner - lar seg ikke 
gjennomføre i akademisk regi. Selskap med store forskningsprosjekter er finansiert med privat risikokapital. Publiseringen av resultater fra kommersielle studier gjøres derfor på en annen måte enn fra akademiske.

For børsnoterte virksomheter finnes det regler for hvilken informasjon som skal formidles og når, og Algeta har fulgt disse til punkt og prikke. De har også fulgt de regler som finnes for innlevering av data til faglige kongresser og de regulatoriske myndigheters regelverk. At de ikke følger alle reglene for akademisk rapportering synes mer eller mindre irrelevant i denne sammenheng.

For aksjemarkedet er det ikke helt uproblematisk at all relevant informasjon ikke foreligger samtidig. Ikke sjelden rapporteres først overordnede data og de kan gi grunnlag for ulikheter i fortolkning. Nå er det aksjemarkedets oppgave å håndtere risiko, også risiko som følger med de kognitive prosessene som er knyttet til utvelgelse og fortolking av informasjon. Noen ganger tar markedet feil, feilprising forekommer i ineffisiente markeder, det vil si i de tilfeller hvor all tilgjengelig informasjon ikke umiddelbart reflekteres korrekt i aksjekursen. Men ikke så i Algetas tilfelle. Kursreaksjonen etter 6. juni var høyst adekvat. Økningen i aksjekursen reflekterte både tidsverdien og kostnadsreduksjonen av avbruddet av studien og den risikoreduksjonen som fulgte av de data som ble presentert. Dette er blitt bekreftet gjennom de utfyllende data som Algeta presenterte på den store kreftkongressen EMCC 2011 /ESMO - data som for øvrig var ute før Tidsskriftet publiserte sin lederartikkel (2). Her er studiedesign og resultat for alle målepunkt fagfellevurdert og behørig presentert. Dermed er også komplette datasett langt på vei presentert for fagmiljøene, og vi har lenge kunnet se at det er svært sannsynlig at «resultatene med Alpharadin viser seg å holde stikk».

Det nevnte eksempel viser ikke at «børser lever godt med rykter og mangelfull informasjon». Det gjør børser ikke, når de fungerer som de skal. Når de ikke fungerer som de skal, styrer ryktene og mangelen på informasjon. Hem risikerer her at hans gode poeng går tapt fordi eksemplet som er valgt ikke er treffende.

\section{LITTERATUR}

1. Hem E. Børsrakett forlenger livet? Tidsskr Nor Legeforen 2011; 131:1985.

2. The Royal Marsden NHS Foundation Trust. Overall survival benefit of radium-223 chloride (Alpharadin) in the treatment of patients with symptomatic bone metastases in castration-resistant prostate cancer (CRPC): a phase III randomised trial (ALSYMPCA). http://kundeweb.aggressive.no/users/algeta2.no/filer/Parker\%20ALSYMPCA\%20-\%20ESMO\%202011 \%20Alpharadin\%20Oral\%2oPres \%20-\%20AuRev\%2012\%20092111.pdf(7.12.2011).

Publisert: 10. januar 2012. Tidsskr Nor Legeforen. DOI: 10.4045/tidsskr.11.1296

(C) Tidsskrift for Den norske legeforening 2023. Lastet ned fra tidsskriftet.no 26. april 2023. 